\title{
Message From The New President
}

I JUST RETURNED FROM the first of a new type of TOS meeting-the Pacific Basin "focus" meeting. We had an outstanding opportunity to hear the results of the large Pacific Basin programs of the past few years, WOCE, TOGA-COARE, JGOFS EqPac, and RIDGE. The meeting reflects the TOS Council's interest in providing new services to our members. The topic of our services to members has been high on our list of efforts and has been on my mind as I think about my term as president of the society. Jim Baker, our first president, viewed his role as one of generating excitement about the possibilities of a new society for oceanographers that fully realized and capitalized on the interdisciplinary aspects of our science. Arnold Gordon, our second president, saw his job as ensuring that the society made it through that period of initial euphoria, that we had a regular scientific meeting of interest and high scientific quality, and that our magazine began a regular publishing schedule. I think both succeeded and we owe them great thanks.

Where do we go from here? Listening to you at TOS meetings and reading your letters in Oceanography, it seems clear to me that we do not have clear agreement on our goals as a society, and more importantly, have not clearly defined the ways in which we can and should serve you as members. For example, I see concerns over the poor coverage of international oceanographic programs in our meetings and magazine. Within the Council of the Oceanography Society, the lack of a clearly defined direction makes it difficult for us to prioritize possible projects that we should take on. I see my principal task as helping the society to decide on its function and its goals and to set its priorities for activities in the next few years.

I asked the Council to join me in sessions during our last two meetings to prepare some proposals to present to you. Our first priority must be to define the community that we serve. Should we be a society like the American Meterological Society that seeks to represent academics, professionals (government and private), educators, and students? Should we continue on our present path, which appeals primarily to academics and government professionals? The answer to this important question will determine not only what we do in the future but how we do it. For example, if we represent all those whose work relates to the ocean, we might want to consider professional services and educator services. I asked that the TOS Council consider for each of six possible constituencies (academic and agency researchers, students, government and industry professionals, undergraduate and other educators, and the public) the implications for membership, services, representation, advocacy, job and other career information, publications, meetings, topical-regional focus (e.g., blue-green-brown water issues), and which other societies and organizations represent this constituency.

The Council presented the results of its deliberations to our business meeting in Hawaii, and we are presenting them in this issue of Oceanography. You will have several months to comment through letters to Oceanography magazine and/or to the Council. On the basis of your responses, we expect to develop a plan for the society and to present it at the April 1995 meeting in Newport, Rhode Island.

In the meantime, we expect to expand the international focus of both the Society and Oceanography Magazine. We are discussing plans to have our 1996 meeting outside of the U.S. and to focus on a topic that will be of international interest. We also plan to add a new section to Oceanography magazine that has an explicitly international focus, allowing us to report news of other international marine societies.

-Margaret Leinen
Infrared $\mathrm{CO}_{2}$ Analyzers for Atmospheric Research

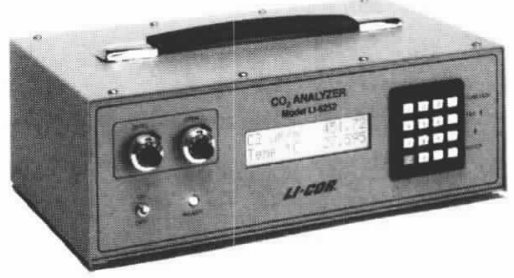

LI-6252 $\mathrm{CO}_{2}$ Analyzer

- Range: 0 - 3000 ppm.

- High accuracy - signal noise below 0.2 ppm peak-to-peak at $350 \mathrm{ppm} \mathrm{CO}_{2}$.

- Portable, solid-state, insensitive to vibration.

- Fast response (1 second; 0.1 second optional).

- Absolute or differential operation.

\section{LI-6262 $\mathrm{CO}_{2} / \mathrm{H}_{2} \mathrm{O}$ Analyzer}

- Simultaneous $\mathrm{CO}_{2}$ and $\mathrm{H}_{2} \mathrm{O}$ measurements from $\mathrm{O}$ - 3000 ppm $\mathrm{CO}_{2}$ and 0 to 75 millibars $\mathrm{H}_{2} \mathrm{O}$.

\section{LI-610 Portable Dew Point Generator}

- Generates gas with a stable dew point from 0 to $50{ }^{\circ} \mathrm{C}$.

- Accurate to $\pm 0.2{ }^{\circ} \mathrm{C}$.

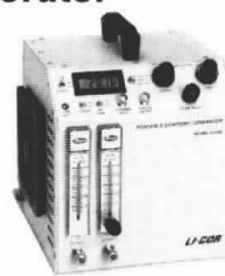

Call 1-800-447-3576 for a free Brochure Toll free, U.S. \& Canada

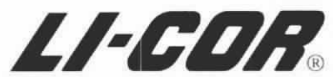

Over 20 Years of Service

LI-COR, inc - P. Box 4425 - Lincoln, NE 68504 USA TWX:910-621-8116 • FAX: 402-467-2819 